\title{
PROVIDING A NEW APPROACH TO ASSESSING TOURISM SUITABILITY IN IRAN (CASE STUDY: BADAREH CITY, ILAM PROVINCE, ZAGROS REGION)
}

\author{
Ali NAJAFIFAR* \\ Research Division of Natural Resources, Ilam Agricultural and Natural \\ Resources Research Center (AREEO), Ilam, Iran, e-mail: alinajafifar@yahoo.com.
}

Jafar HOSEINZADEH

Ilam University, Department of Forestry, Faculty of Agriculture, Ilam, Iran, e-mail: j.hoseinzadeh@gmail.com

Hamidreza MOJARADI-GILAN

Department of Jahad-e-Daneshgahi (ACECR), Kermanshah, Iran, e-mail: hd.mojaradi@gmail.com

\begin{abstract}
Citation: Najafifar, A., Hoseinzadeh, J., \& Mojaradi-Gilan, H. (2019). PROVIDING A NEW APPROACH TO ASSESSING TOURISM SUITABILITY IN IRAN (CASE STUDY: BADAREH CITY, ILAM PROVINCE, ZAGROS REGION). GeoJournal of Tourism and Geosites, 26(3), 780-793. https://doi.org/10.30892/gtg.26309-397
\end{abstract}

\begin{abstract}
Tourism suitability in Iran is evaluated using a systematic model in the form of two macro scales (extensive and intensive). The purpose of this study was to introduce a new approach in this regard based on the capabilities of all components of tourism land-uses and in accordance with new techniques and methods of assessment. Evaluation criteria were distributed in two general and specific groups using fuzzy logic. General criteria were involved in the evaluation of all tourist landuses, but specific criteria were specific to the evaluation of a particular land-use. The weight of land-use evaluation criteria, the weight of general criteria relative to the specific criteria as well as the weight of land-uses were determined in assessing the total tourism suitability of the region based on the ANP and Delphi techniques. Finally, the capability of each tourism specific land-use and the total tourism capabilities of the region were assessed based on the layers of specific and general criteria using the WLC linear approach, and then, along with other land-uses of the region, was explored using the MOLA exploratory method. The area allocated to five land-uses of climbing, picnic and camping, kite and gliders, rock climbing and snowboarding were $61.8,2,4.2$ and 4.3 and 4 percent, respectively. The value for visiting archaeological and cultural assets and the average total value of tourism in the region were determined to be 178.5 and 47 (in the fuzzy range of $0-255$ ), respectively. Providing accurate assessment of tourism suitability using the cluster structure based on their respective land-use capabilities and through the use of digital multi-factor evaluation techniques with fuzzy logic and ANP weighting technique are the benefits of this new approach.
\end{abstract}


Words: Analytic Network Process, Evaluation Model, Fuzzy Logic, Tourism, Weighted Linear Combination

\section{INTRODUCTION}

The continuous increase of tourism destinations and the volume of investments on this has made the tourism industry a key driver of the progress of the countries' economy (UNWTO, 2017). The optimal evaluation of tourism is always an important challenge for managers and its consideration in the planning of multiple uses of forest areas has a double importance in terms of the sustainability of these ecosystems.

The evolution of the early studies of the status quo (existent) situation of the land (in terms of inventory and demand) has changed to explore the possible capability of tourism in terms of tourism resources or capability (Iatu, 2010). There are two main trends in describing tourism potential. Glavan, defines it as "the sum of possibilities that the natural and social environment puts at disposal of tourism activities" (Glavan, 2000).

On the contrary, (Muntele \& Iatu, 2006) considered it the "set of objective and subjective conditions", and other similar definitions, their main approach focusing on its immaterial nature of the assessment of tourism capability. The immaterial approaches emphasize that tourism capability is a prerequisite and a reliable precondition for the possible occurrence of tourism activity in a particular region (Iatu, 2010). Since the mid-1990s, there are more sophisticated geo-cultural approaches in the tourism assessment based on the ability of natural or human elements in the form of surveys of social mentality (tourist interests) (O'Riordan, 1971). Attractiveness is an important tool for measuring the tourism system. The approaches to evaluate the attractiveness of tourism was developed by Smith (Smith, 1987). This approach provides a better description of the relationship between the possible and the actual status of tourism (existent) and between the Supply and the Consumed (Boyd et al., 1995). Important research resources have been reported in assessing tourism capability based on the potential of attractiveness (Berry, 1991; Boyd \& Butler, 1996; Priskin, 2001; Tsaur et al., 2006; Dezsi, 2008; Ielenicz \& Comanescu, 2009; Asami et al., 2009; McClinchey \& Carmichael, 2010).

Various approaches to tourism attraction study are based on resource classification and landscape quality assessment methods, as well as landscape assessment through the bachelor's knowledge, visual rating, field surveys and aerial imagery analysis (Litton, 1968). Aerial imagery has been widely used in landscape attractiveness assessment (Lynch \& Gimblett, 1992). From other common approaches to assessing the attractiveness of tourism is the approach based on the assessment of demand using the views of tourists and locals based on the expert knowledge (Ferrario, 1979; Dowling, 1993; Cohen et al., 2014; Song et al., 2014). Landscape-based assessment techniques based on the scenic quality indices have also been used extensively in tourism valuation studies (Moss \& Nickling, 1980; Mitchell, 1989; Cocklin et al., 1990; Yildirim \& Olmez, 2008; Marzuki, 2011). In New Zealand, a method for assessing tourism is presented with a combination of two approaches of landscape quality assessment and assessment based on land-uses.

The classification of resources in this method is based on the elements of landscape type and land cover using aerial images, topography and field controls (Cocklin et al., 1990). Moreover, a method for evaluating natural tourism resources based on the approach of qualitative classification using the qualitative weighting system is presented (Priskin, 2001). In the past, due to the lack of digital processing in the form of spatial information 
systems and limitations in the number of measurable spatial options, the process of collecting and analyzing data and deciding on the initial evaluation models is often accomplished through overlapping of Polygon maps and at the level of micro-ecosystems of the land. The above-mentioned approach was first proposed by MiekharK using the method of overlaying of ecological layers (McHarg, 1969). Worldwide, using this approach has been developed based on traditional mapping techniques or in conjunction with GIS.

Another approach to assessing the land in the past was the method of networks that was prevalent in the UK. In this method, the land is evaluated in the form of a network of quadrangle and based on the average values of the characteristics of the samples, and then, the final strategy is adopted by adding other criteria such as wildlife conservation and land-use (Smith, 1982). The quadrangle size used in this method varies from one to 10 square kilometers (Makhdoom, 2006). With the development of GIS capabilities, it is possible to evaluate the land based on the base pixel maps, which is in fact the development of the method of networks in the form of squared units with much smaller dimensions, so that, today, most evaluation studies are using multi-criteria methods based on the pixel maps (Berry, 1991; Boyd \& Butler, 1996; Ringo Linder, 2009; Suvdantsetseg, et al., 2010; Suvdantsetseg et al., 2011).

The Makhdoom (2006) systemic spatial planning method, which has been used for many years in Iran, is, in fact, derived from the Machart ecosystem boundary. The spatial planning in this method is carried out using two sug models (qualitative-deductive and corrected quantitative-deductive) of Nakos (1984). The tourism assessment model of the above method is still used in Iran (Pirmohammadi et al., 2010; Eskandari et al., 2013; Karami et al., 2014; Ghadiri Masoom et al., 2015; Ahmadi Sani et al., 2016). Tourism capability in the systemic method is evaluated in the form of main classes of extensive and intensive categories. However, in recent years, few attempts have been made to evaluate the specific capabilities of some tourism land-use in Iran, but so far, the lack of a comprehensive model that allows land-use tourism evaluation on the basis of various landuse details and in accordance with modern conditions and techniques is evident.

In this regard, the use of geometric means of criteria in ecotourism evaluation is considered more appropriate than the systematic method (Jokar et al., 2014). Moreover, in carrying out a research, five land-use capabilities including climbing, skiing and winter sports, nature therapy (hot springs), and water sports and fishing in the Sabalan region were evaluated using the boolean functions (Movahedi et al., 2013). Studies on comparing tourism suitability in different regions of Iran have also been done using TOPSIS multi-criteria decision making method (Asadi \& Daryaei, 2011; Amanpour et al., 2012; Nasrollahi et al., 2014). According to the World Economic Forum's 2017 report, Iran ranked 93 and 119 in terms of competitiveness and environmental sustainability indicators (Schwab, 2017). Accordingly, presentation of a suitable tourism assessment approach allows for the proper recognition of existing capabilities and promotion of environmental sustainability indicators in the development of Iran. The purpose of this study was to introduce a comprehensive land-use Tourism Assessment Model, in line with newly evaluated and flexible techniques for adaptation to different regions of Iran.

\section{RESEARCH AREA}

This study was carried out in western Iran, in the southern Zagros Growth Block, located in the northern heights of Kabirkouh, Badra city, Ilam province. Iran is located in Southwest Asia (Middle East). It is bounded on the south by Khuzestan province, on the east by Lorestan province, on the north by Kermanshah province, and on the west by Iraq country. The average rainfall of the 30 year period is $572 \mathrm{~mm}$, based on Ilam Meteorological 
Station data. The ombrothermic diagram of the station indicates that the region has a dry period (the vegetative period of the trees) from mid-May to late October.

The study area is $16,825^{\text {ha }}$ and its extends from $33^{\circ} 13^{\prime} 12^{\prime \prime}$ to $33^{\circ} 23^{\prime} 1^{\prime \prime}$ northern latitudes and extends from $46^{\circ} 53^{\prime} 27^{\prime \prime}$ to $47^{\circ} 5^{\prime} 4^{\prime \prime}$ eastern. The alltitude range is from 700 to 2500 meters above sea level. The geographic location image of the study area is presented in Figure 1. The geomorphic facies of the area are mountainous and the vegetation cover is the woodland with the dominant species of oak (Quercus Branti). Natural features and a fair variety of tourist attractions are the reasons for choosing this area.

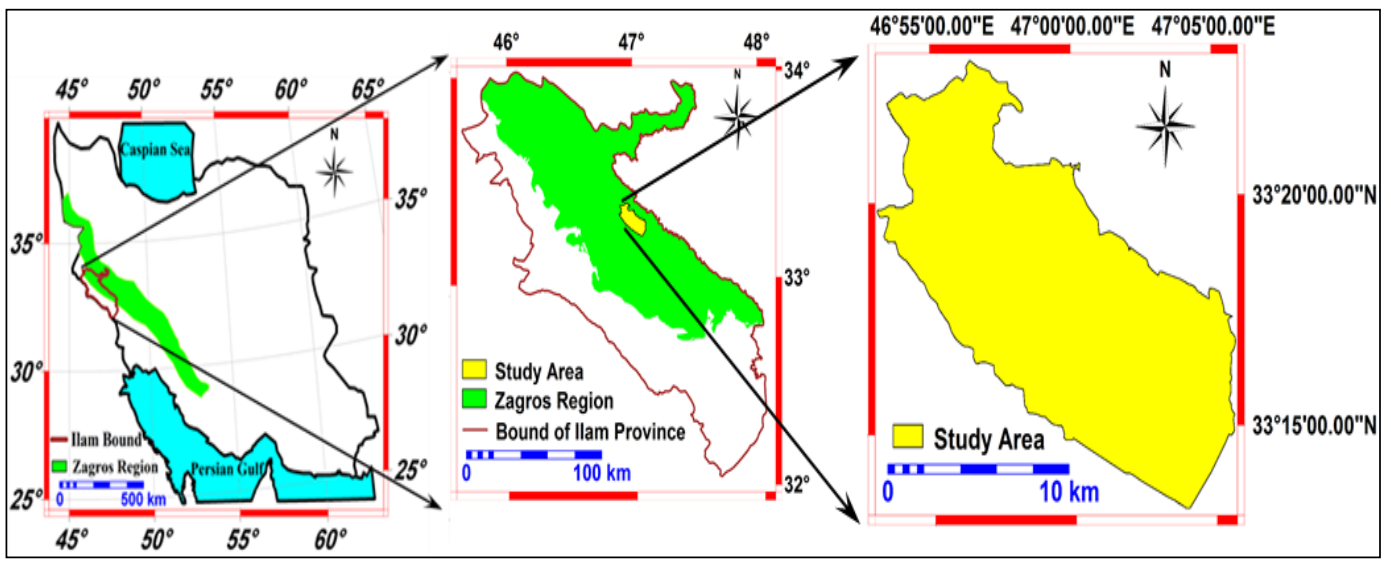

Figure 1. Location Map of the study area in the Ilam Province, Zagros region and Iran

\section{RESEARCH METHOD}

In this research, a new sustainable approach was introduced to evaluate tourism suitability. In this approach, firstly, tourism land-uses were evaluated separately and then the overall tourism functioning was determined based on it. Accordingly, the criteria for evaluation were divided into two general and specific groups. The general criteria included the factors that contribute to the assessment of the capability of all tourism land-uses and, instead, the specific criteria are exclusively specific to the land-use type being evaluated. Evaluation criteria were selected according to environmental sustainability indicators. In the implementation of research, first, the overall capability of the region in terms of general tourism criteria and then the ability to develop current or potential tourism uses based on specific criteria were evaluated. For this purpose, the weight of the criteria related to the models for assessing the land-uses and the general and specific criteria relative to each other, as well as the weight of each land-use, in the general tourism capability assessment model was determined using the ANP (Analytic Network Process) method.

For this, clustering of the network structure of the criteria and sub-criteria and the survey forms profile were determined based on a review of the sources, experts' opinion and Delphi methodology. The ANP process can be divided into two parts: control hierarchy and network communication. The control hierarchy incorporates the relationship between the goal, the criteria and the sub-criteria, influences the internal relationship of the system, and the network relationship show the dependence between elements and clusters. ANP is done in four different stages. The first step is to build the model and convert the problem into a network structure. The formation of a binary comparison matrix and determination of priority vectors and then, the formation of unweighted super matrix and its conversion to the limit super matrix were carried out in 
steps two and three, respectively, and finally, in the final step, a ranking was made for the evaluation criteria (Zabardast, 2010). The survey was conducted on the basis of the views of 20 experienced experts working in the Zagros Research and Implementation Departments. The comparison of the fuzzy network analysis criteria or sub-criteria is described in Table 1 and were performed based on the geometric mean of the paired comparison, the views of different experts with a maximum inconsistency rate of 0.1. Eigen-vector of the network model was calculated based on the results of the sum of paired comparison (Saaty, 1999), in the form of logarithmic least squares method (Lin \& Hsu, 2011).

Table 1. Fuzzy spectrum and its corresponding verbal phrases

to compare the criteria of the ANP model (Data source: (Lin \& Hsu, 2011)

\begin{tabular}{c|c|c|c|c|c|c|c|c}
\hline Code & $\begin{array}{c}\text { Verbal } \\
\text { phrase }\end{array}$ & $\begin{array}{c}\text { Fuzzy } \\
\text { numbers }\end{array}$ & Code & $\begin{array}{c}\text { Verbal } \\
\text { phrase }\end{array}$ & $\begin{array}{c}\text { Fuzzy } \\
\text { numbers }\end{array}$ & Code & $\begin{array}{c}\text { Verbal } \\
\text { phrase }\end{array}$ & $\begin{array}{c}\text { Fuzzy } \\
\text { numbers }\end{array}$ \\
\hline 1 & $\begin{array}{c}\text { Equal } \\
\text { preference }\end{array}$ & $(1,1,1)$ & 4 & $\begin{array}{c}\text { Moderate to } \\
\text { high } \\
\text { preference }\end{array}$ & $(3,3.5,4)$ & 7 & $\begin{array}{c}\text { Extremely } \\
\text { high } \\
\text { preference }\end{array}$ & $(5,5.5,6)$ \\
\hline 2 & $\begin{array}{c}\text { Low to } \\
\text { moderate } \\
\text { preferences }\end{array}$ & $(1,1.5,1.5)$ & 5 & High preference & $(3,4,4.5)$ & 8 & $\begin{array}{c}\text { hxtremely } \\
\text { high to quite } \\
\text { high } \\
\text { preference }\end{array}$ & $(5,6,7)$ \\
\hline 3 & $\begin{array}{c}\text { Moderate } \\
\text { preference }\end{array}$ & $(1,2,2)$ & 6 & $\begin{array}{c}\text { High to } \\
\text { extremely high } \\
\text { preference }\end{array}$ & $(3,4.5,5)$ & 9 & $\begin{array}{c}\text { Quite high } \\
\text { preference }\end{array}$ & $(5,7,9)$ \\
\hline
\end{tabular}

In the next step, the eigen-vector (Wij) matrices derived from the paired comparison of the second stage were used to calculate the final weight of the components of each level based on Equ 1 (Lin \& Hsu, 2011).

Equ 1: $\quad W_{i}^{*}=\mathrm{W}_{i i} \times \mathrm{W}_{i(i-1)} \times W_{i-1}^{*}$

In Equ 1, $\left(W_{i}^{*}\right)$ is final weight of the components of level I, $\left(\mathrm{W}_{\mathrm{ii}}\right)$ is eigen-vector matrix of the internal relations, $\left(\mathrm{W}_{\mathrm{i}(\mathrm{i}-1)}\right)$ is eigen-vector of the level $\mathrm{i}$, and $\left(W_{i-1}^{*}\right)$ is final weight of the higher level. If there is no $W_{\text {ii }}$ matrix for a level, an identity matrix is replaced by Equ 2.

Equ 2: $\quad W_{i}^{*}=I \times W_{i(i-1)} \times W_{i-1}^{*}$

In Equ 2, Parameters $\left(W_{i}^{*}\right),\left(\mathrm{W}_{\mathrm{ii}}\right)$ and $\left(\mathrm{W}_{\mathrm{i}(\mathrm{i}-1)}\right)$ are described in equation 1. (I) is the identity matrix and its value is 1 .

In the end, the final capability of each specific land-use was determined based on the utility layout of the specific and general criteria and according to the weight of each of these layers using the WLC method. In combination of general and specific layers, in order to evaluate the ultimate land-use capability, visiting national cultural works, instead of directly using the general criteria layer, the average value of the pixels of the mentioned layer, which has a fixed value throughout the study area, has been used. Suggested land-uses in the proposed assessment model include snowboarding; mountaineering, horseback riding, hunting and watching wildlife; picnic and camping; kite and gliders; rock climbing; visiting ancient monuments, national and cultural traditions; tourism in the seas and large lakes; tourism in inner-waters, hot springs, black tourism; driving in nature; national and ancient works; and desert touring. It should be noted that it is possible to delete or add any new land-use in the structure of the model depending on the new spatial and temporal conditions. Current or potential tourism land-uses which can be evaluated in the study area include snowboarding, climbing and related activities, Kite and Glider station, climbing, Picnic and Camping, and 
visiting national-cultural works. Therefore, in the overall tourism assessment model, zero-value was allocated to tourism land-uses in seas and large lakes; hot springs; black tourism; nature driving and desert touring in the study area lacking the minimum capability for tourism assessment. Ultimately, general capability of tourism industry, based on all of the utility layers of the evaluated land-uses, was achieved with consideration of the relevant weights.

In the proposed model, information layers related to the assessment of various tourism land-use capabilities were used directly in the spatial planning. At the same time, in order to make it possible to compare and prioritize the capability of land-use tourism among different regions, extensive and intensive tourism suitability maps, water tourism as well as general tourism capability maps were prepared. In assessing the overall tourism capability, while determining the weight of all evaluated land-uses, the linear combination of these layers was considered. Finally, the average value of the pixels of the overall tourism map was proposed as a benchmark for comparison between the regions. In sum, the proposed tourism model is based on the inductive logic (total evaluation based on details) of two sub-models and a main model (final model). The first sub-model was the assessment of the study area in terms of general tourism standards. The second sub-model is dedicated to assessing the various tourism land-uses based on specific criteria and comparing it with general criteria. In this sub-model, the capability of the area was evaluated in terms of five different tourist land-uses.

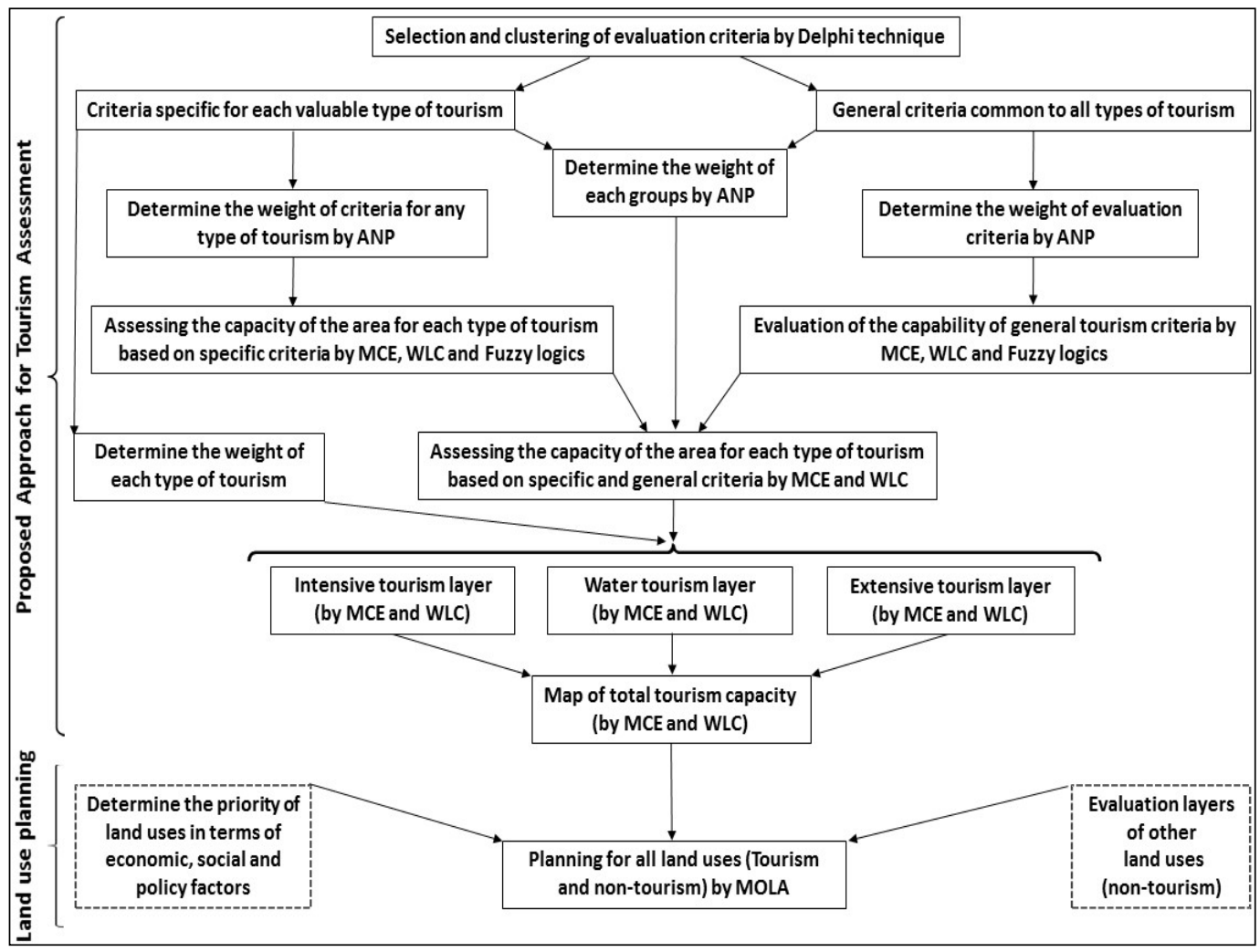

Figure 2. The flowchart of the main steps in the suggested approach for tourism assessment

The final evaluation of the capability of each tourism land-uses requires the determination of the weight of each of the general and specific criteria which was 
obtained using the questionnaire in the form of ANP models. In the main model, the tourism suitability was evaluated using desirable layers of land for different uses.

Eventually, three land-use inconsistencies including rock climbing, picnic and camping and snowboarding were used for exploration of MOLA (Multi Objective Land Allocation) compared with other non-tourism land-uses and the final map of the spatial planning was presented. The flowchart of the main steps in the suggested approach for tourism assessment is presented in Figure 2.

\section{FINDINGS}

The sub-model of general tourism criteria consists of three socio-economic, aesthetic and climatic criteria. The socioeconomic factors include two sub-criteria of population (number, income and distance) and accessibility parameters. The aesthetic factor also includes two sub-criteria of the beauty of the landscape, the view extension and the climatic factors include the two sub-criteria of the number of sunny days in the visiting season and the average temperature of the visiting season.

Finally, the sub-criteria of accessibility include three sub-criteria of roads, railways and airports, and the sub-criteria of the extent of view include two sub-criteria of depth of vision and vision azimuth. The results of prioritization of the sub-criteria of the general model of tourism are presented in Table 2. For example, Picnic and Camping models were presented among the sub-models of specific criteria. The land-use assessment model, like all other tourist land-uses, is made up of two criteria of general and specific factors. Subcriteria of general factors have already been discussed in the form of the relevant model.

The criteria for specific factors include soil factors, topography, drinking water, covering, attractiveness of the tourism and local access. Soil factors are subdivided into soil depth, soil texture and bedrock type, the topographic factors are classified into slope and Hillshade sub-criteria, and the drinking water, attractiveness, covering and local access had no sub-criteria. The results of the prioritization of the sub-criteria of the Picnic and Camping model are presented in Table 3. The ANP's main model for assessing the total tourist land-use is composed of three criteria: Water Tourism, Extensive Tourism, and Intensive Tourism. Water tourism includes three sub-criteria of tourism in large waters (large seas and lakes), tourism in small waters (rivers and lakes) and hot water resources. Extensive Tourism includes six sub-criteria of rock climbing, mountain climbing and related uses, kite and gliders, desert touring, nature driving and black tourism, and intensive Tourism includes three sub-criteria of snowboarding, Picnic and Camping, and visiting national monuments and local customs.

The results of the prioritization of the sub-criteria of the main tourism suitability assessment model are presented in Table 4. According to ANP results in prioritizing tourism land-uses (Table 4), the weight of the relevant land-uses for each tourism group was calculated regarding the corresponding group and presented in Table 5. Accordingly, the land desirability layers were prepared for two extensive and intensive groups. The study area lacked the necessary resources for water dependent uses.

The map of the area capability is presented in Figures 2, 3, 4, 5, 6, and 7, respectively, in terms of general tourism criteria and the specific capabilities of skiing, mountain climbing, kite and glider stations, rock climbing and picnic and camping. The capability to visit archaeological, national and cultural monuments was also determined at 178.5 of the total study area. The water tourism suitability unique to the lake of Seymare Dam was determined alongside the study area to be 204. Given that the average value of the pixels for the general criteria layer for water tourism was 79 (weight of 0.4 ), its final value was 154 . 
Providing a New Approach to Assessing Tourism Suitability in Iran

(Case Study: Badareh City, Ilam Province, Zagros Region)

Table 2. The results of prioritizing the sub criteria of the general criteria model

\begin{tabular}{|c|c|c|c|c|c|c|c|c|c|}
\hline Sub Criteria & Sum & Normal & Ideal & Rank & Sub Criteria & Sum & Normal & Ideal & Rank \\
\hline LA $^{1}$ & 0.124 & 0.316 & 1 & 1 & Airport & 0.028 & 0.070 & 0.223 & 5 \\
\hline DDEPI $^{2}$ & 0.101 & 0.257 & 0.813 & 2 & Railway & 0.024 & 0.060 & 0.191 & 6 \\
\hline Road & 0.039 & 0.100 & 0.316 & 3 & AAAT & 0.024 & 0.060 & 0.190 & 7 \\
\hline Visibility & 0.036 & 0.092 & 0.292 & 4 & ANSD & 0.018 & 0.046 & 0.144 & 8 \\
\hline
\end{tabular}

1. Landscape Aesthetics; 2. Density, distance and employment of population Index;

3. Average Annual Air Temperature; 4. The Annual Number of Sunny Days

Table 3. The results of prioritizing the sub criteria of the picnic and camping model

\begin{tabular}{|c|c|c|c|c|c|c|c|c|c|}
\hline Sub Criteria & Sum & Normal & Ideal & Rank & Sub Criteria & Sum & Normal & Ideal & Rank \\
\hline Attractiveness & 0.252 & 0.473 & 1 & 1 & Soil Depth & 0.020 & 0.038 & 0.080 & 6 \\
\hline Slop & 0.065 & 0.123 & 0.259 & 2 & Hillshade & 0.018 & 0.033 & 0.070 & 7 \\
\hline Quant \& qual of water & 0.062 & 0.116 & 0.246 & 3 & Bedrock material & 0.015 & 0.028 & 0.060 & 8 \\
\hline Forest Canopy & 0.050 & 0.093 & 0.197 & 4 & Soil texture & 0.013 & 0.024 & 0.050 & 9 \\
\hline Local access road & 0.038 & 0.071 & 0.149 & 5 & & & & & \\
\hline
\end{tabular}

Table 4. The prioritization of the sub-criteria of the main tourism suitability assessment model

\begin{tabular}{|c|c|c|c|c|c|c|c|c|c|}
\hline $\begin{array}{c}\text { Tourism } \\
\text { Land-uses }\end{array}$ & Sum & Normal & Ideal & Rank & $\begin{array}{c}\text { Tourism } \\
\text { Land-uses }\end{array}$ & Sum & Normal & Ideal & Rank \\
\hline $\begin{array}{c}\text { Picnic and } \\
\text { camping }\end{array}$ & 1.0 & 0.286 & 0.143 & 1 & $\begin{array}{c}\text { Rock } \\
\text { climbing }\end{array}$ & 0.183 & 0.053 & 0.026 & 7 \\
\hline $\begin{array}{c}\text { visiting ancient } \\
\text { and national }\end{array}$ & 0.500 & 0.143 & 0.072 & 2 & $\begin{array}{c}\text { Kite and } \\
\text { gliders }\end{array}$ & 0.156 & 0.045 & 0.022 & 8 \\
\hline $\begin{array}{c}\text { Seas and large } \\
\text { lakes }\end{array}$ & 0.467 & 0.134 & 0.067 & 3 & $\begin{array}{c}\text { Driving in } \\
\text { nature }\end{array}$ & 0.147 & 0.042 & 0.021 & 9 \\
\hline Mountain-eering & 0.423 & 0.121 & 0.061 & 4 & Inner-waters & 0.102 & 0.029 & 0.015 & 10 \\
\hline Snowboarding & 0.202 & 0.058 & 0.029 & 5 & Hot springs & 0.061 & 0.018 & 0.009 & 11 \\
\hline Desert touring & 0.192 & 0.055 & 0.027 & 6 & Black tourism & 0.060 & 0.017 & 0.009 & 12 \\
\hline
\end{tabular}

Table 5. ANP results on prioritizing tourism activities in the study area

\begin{tabular}{|c|c|c|c|c|c|c|c|}
\hline $\begin{array}{l}\text { Tourism } \\
\text { category }\end{array}$ & $\begin{array}{l}\text { Tourism } \\
\text { activities }\end{array}$ & $\begin{array}{l}\text { Weight in } \\
\text { category }\end{array}$ & \begin{tabular}{|c} 
Weight \\
in total \\
activities
\end{tabular} & $\begin{array}{l}\text { Tourism } \\
\text { category }\end{array}$ & $\begin{array}{l}\text { Tourism } \\
\text { activities }\end{array}$ & $\begin{array}{l}\text { Weight in } \\
\text { category }\end{array}$ & $\begin{array}{c}\text { Weight } \\
\text { in total } \\
\text { activities }\end{array}$ \\
\hline \multirow{3}{*}{$\begin{array}{l}\text { Water } \\
\text { tourism }\end{array}$} & Seas and large lakes & 0.740 & 0.134 & \multirow{6}{*}{$\begin{array}{l}\text { Extensive } \\
\text { Tourism }\end{array}$} & \begin{tabular}{|l|} 
Mountaineering \\
\end{tabular} & 0.363 & 0.121 \\
\hline & Inner-waters & 0.160 & 0.029 & & Rock climbing & 0.159 & 0.053 \\
\hline & Hot springs & 0.099 & 0.018 & & Kite and gliders & 0.135 & 0.045 \\
\hline Sum & & 1 & 0.181 & & Desert touring & 0.165 & 0.055 \\
\hline \multirow{3}{*}{$\begin{array}{l}\text { Intensive } \\
\text { Tourism }\end{array}$} & Snowboarding & 0.119 & 0.058 & & Driving in nature & 0.126 & 0.042 \\
\hline & $\begin{array}{l}\text { Visiting national } \\
\text { monuments }\end{array}$ & 0.294 & 0.143 & & Black tourism & 0.051 & 0.017 \\
\hline & Picnic and camping & 0.587 & 0.286 & \multirow{2}{*}{ Sum } & & \multirow[b]{2}{*}{1} & \multirow{2}{*}{0.333} \\
\hline Sum & & 1 & 0.487 & & & & \\
\hline
\end{tabular}

The extensive and intensive tourist suitability maps and the total tourism capability and land use planning map of the study area are also shown in Figures 8, 9, 10, and 11, respectively. The average value of the overall map pixels for general capability of tourism was 47. Based on the assessment and planning maps, from 16825 hectares of the studied area, $61.8 \%, 2 \%, 4.2 \%, 4.3 \%$ and $4 \%$, respectively, were considered appropriate for climbing and related activities, picnic and camping, Kite and Gliders, rock climbing, and snowboarding. 


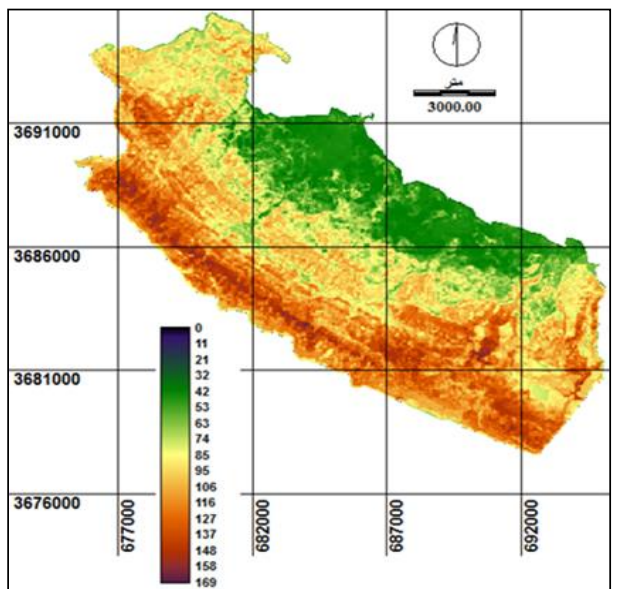

Figure 2. Capability map of the general criteria

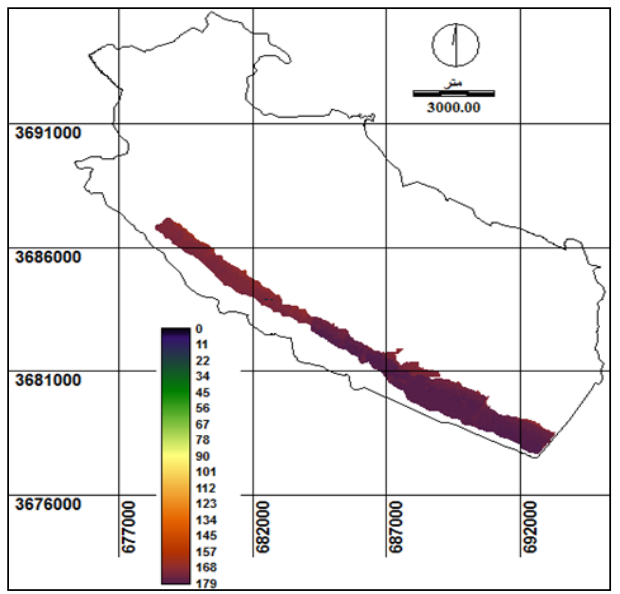

Figure 4. Capability map of the Mountaineering

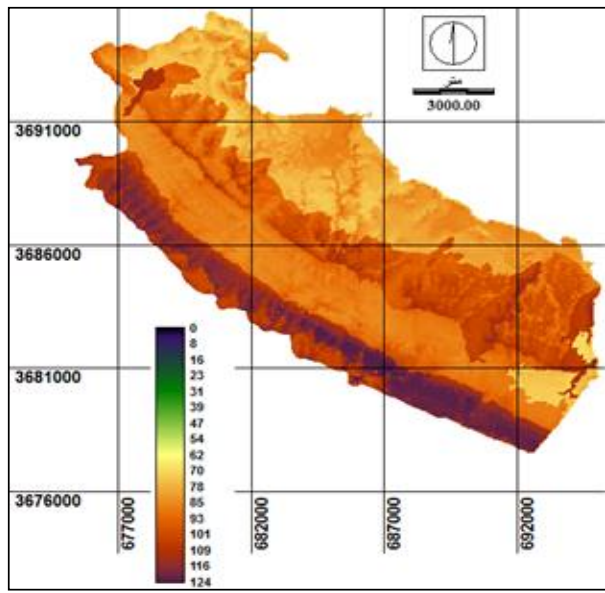

Figure 6. Capability map of the rock climbing

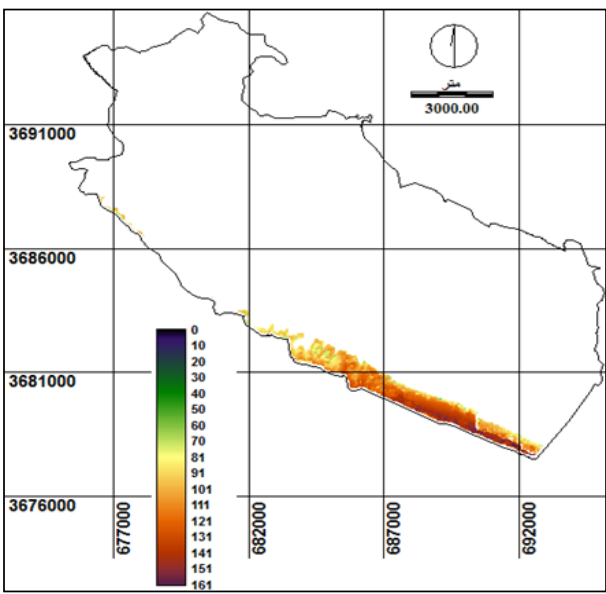

Figure 3. Capability map of the snowboarding station

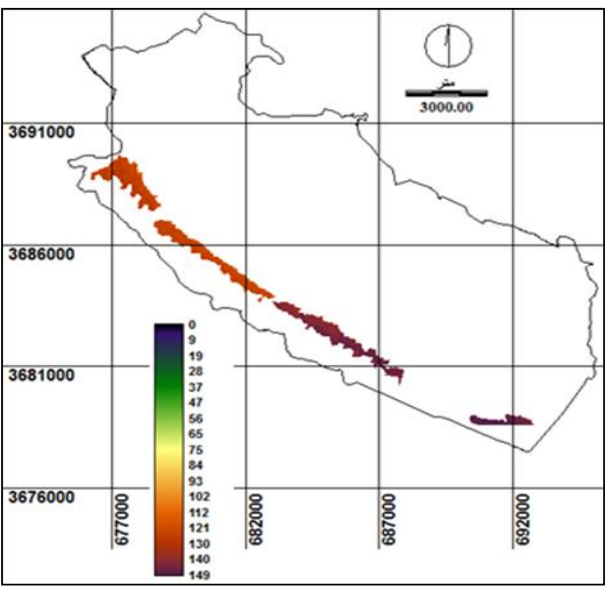

Figure 5. Capabilitymap of the kite or glider station

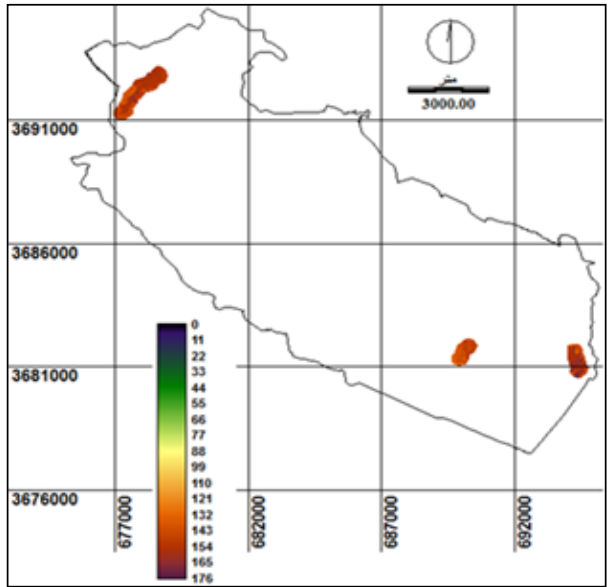

Figure 7. Capability map of the picnic and camping 


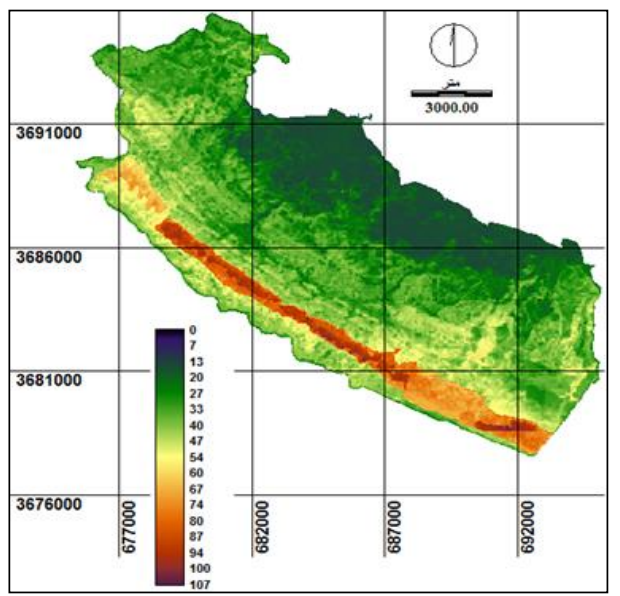

Figure 8. Capability map of the extensive tourism

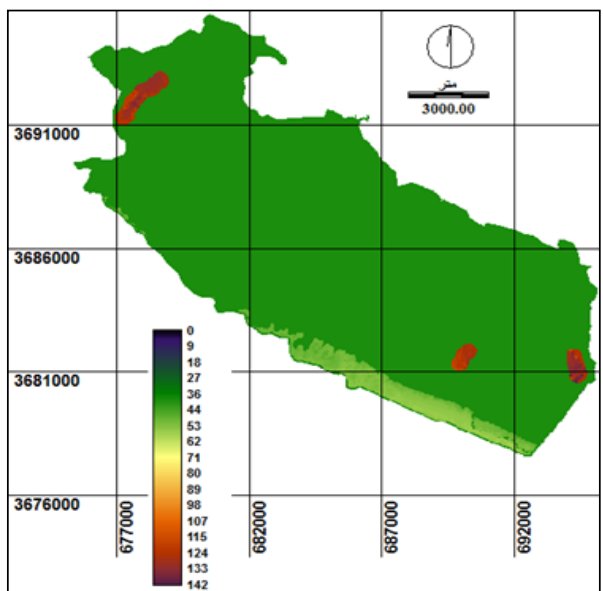

Figure 9. Capability map of the intensive tourism

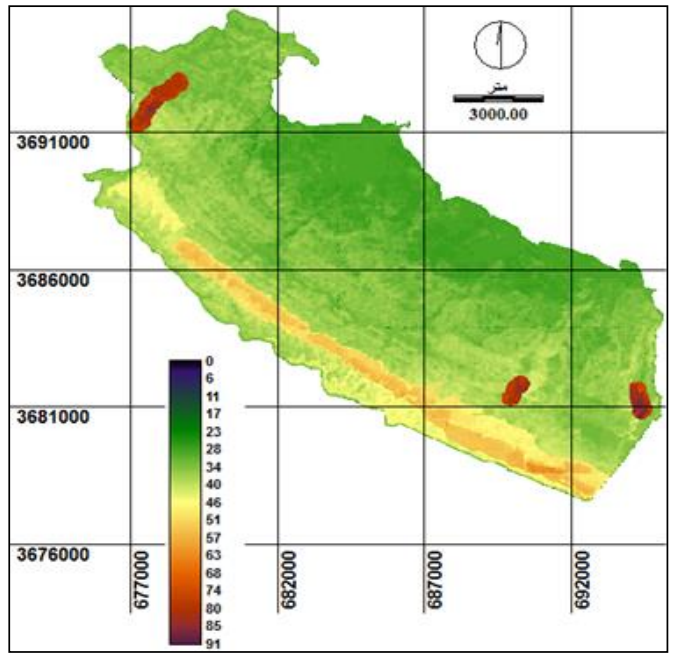

Figure 10. Map of the total tourism potential

\section{DISCUSSION}

The methodology for assessing the ecological potential of the land in Iran and the world is based on the inductive logic of moving from the component to whole. As seen in the sources, the tourism assessment model in Iran, based on its categorization, is divided into extensive and intensive areas (Makhdoom, 2006). Obviously, any analysis from the component to whole should be based on the proper clustering of all details about it, while, the clustering of the current tourism model in Iran is incomplete and the most important element of each cluster, which includes various tourism land-uses, along with the criteria for evaluating it are completely ignored. In other words, in the systematic tourism model, many criteria are being studied and mapped out in the preparation of ecological micro units, however, in practice, the optimal use of this information is not used in the evaluation of various tourism land-uses. On the other hand, the desirability of the land for various types of tourism activities is often different and sometimes contradictory. 
For example, the desirability of the land for activities such as climbing, snowboarding, water recreation or rock climbing are quite different, and therefore, the correct assessment of the land's real potential for tourism is not possible in the form of extensive and intensive classes. In the systematic approach, the tourism suitability is assessed on the basis of the physical conditions of the region (water condition, edaphic, topography, petrology, tree density, and composition of species plants) in extensive and intensive classes in macro scale. Meanwhile, in the new approach, the overall tourism capability or the ability of extensive and intensive classes were correctly assessed based on the aggregation of the capability of a variety of tourism sub-criteria.

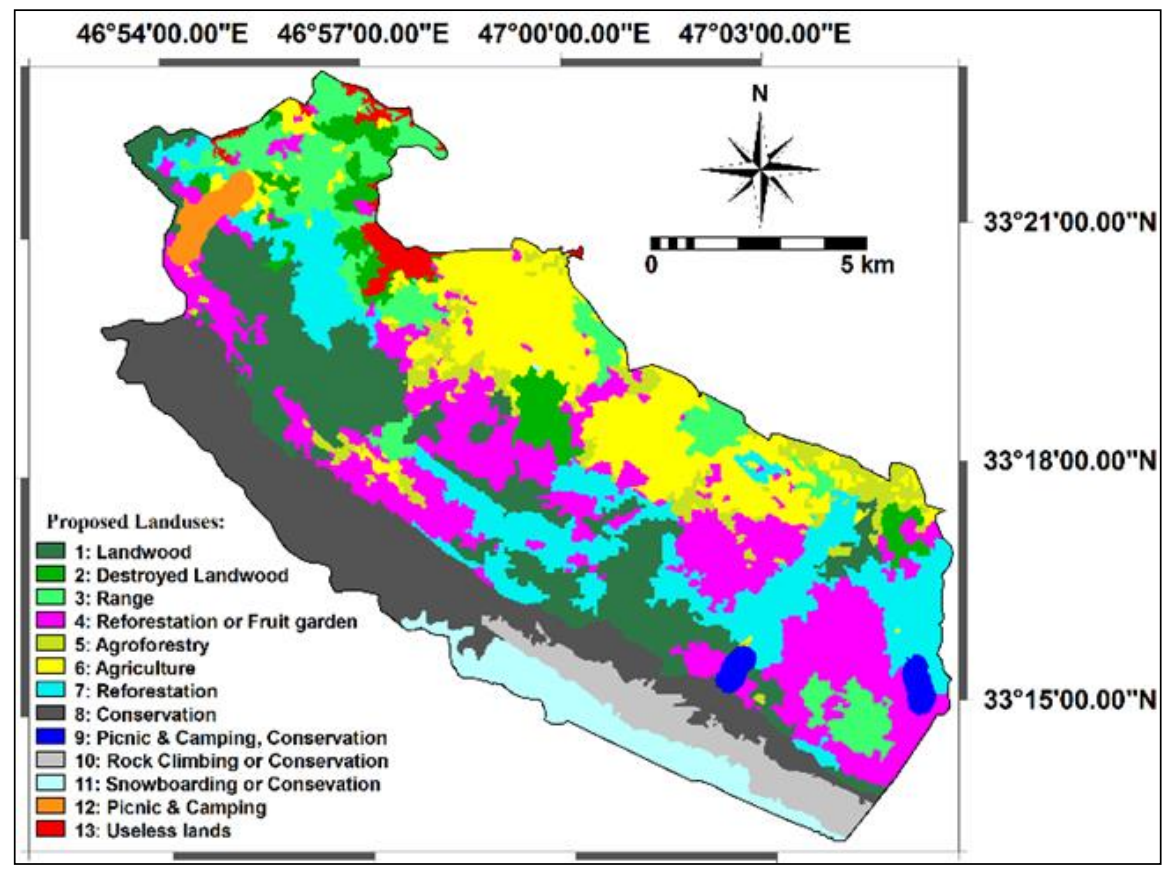

Figure 11. Map of the land use planning

Accordingly, the availability of assessment of tourism suitability for the different types of sub-criteria under assessment is considered as another benefit of the new approach. As noted above, based on the current model in Iran, it is only possible to assess the two types of extensive and intensive tourism in general. Moreover, in the systematic tourism model, there are no references to water tourism, which are of great interest to tourists, and thus, the assessment does not correspond to the type of tourism resources. Based on the proposed approach, tourism classification according to the type of land (dry or water) is more in line with the type of physical structure of the phenomenon and division of land tourism into extensive and intensive areas seems acceptable.

Another advantage of the new approach is to provide an opportunity to assess the capability of all of the tourism sub-criteria in the form of a new proposed model. As noted above, based on the current model in Iran, it is only possible to generally evaluate intensive and extensive tourism. The capabilities of tourism types are highly dependent on various socio-economic factors in the region, and a significant part of these factors can be mapped 
accurately based on GIS. Unlike the traditional Iranian tourism model, in the proposed model of this study, these factors were mapped accurately and used in land-use tourism assessment. On the other hand, in this method, contrary to the systematic method, simultaneous application of all ecological criteria along with a significant part of socioeconomic criteria in order to assess the capability and survey of land for different uses is completely provided. In the evaluation approach, the proposed tourism suitability assessment criteria was reviewed in accordance with the new achievements. The use of the Hillshade index instead of aspect (Najafifar et al., 2017) and the use of the combination index of density, distance, and population employment (Najafifar, 2017) are two examples of this type of change. New criteria for land assessment for tourism is not the value of a land limited to a piece of land with the land-use potential.

But, the value of the land must be determined in proportion to the distance from that point. For example, when a lake is of value to tourism, undoubtedly, tourism suitability and the economy and livelihoods of the surrounding areas are affected by the distance from it. In the proposed tourism approach, it is possible to estimate the land value relative to the distance from the tourism phenomenon using GIS. In using the proposed model, if the purpose of assessment is to determine the general tourism capability and it is not important to determine the capability of different tourist landuses, then the map of all the general criteria of evaluated land-uses can be used in one place to provide a general tourism capability map.

In this research, the average value of pixels belonging to the general tourism map, which was proposed as a benchmark for comparing tourism capabilities between different regions, was found to be 47 in the range of $\mathrm{o}$ to 255. The reason for the low value of the index was the weakness of socio-economic criteria and the lack of accessibility infrastructure, as well as the lack of capability of certain tourism land-uses in many parts of the study area. The strong impact of the accessibility infrastructure and the conditions for the natural phenomena to be seen has been also emphasized in the final assessment of tourism development capabilities in a study conducted in Canada (Boyd et al., 1995).

\section{CONCLUSION}

Providing sustainable assessment of tourism suitability using the cluster structure, consists of available land-use capabilities, based on the use of digital multi-factors, evaluation techniques with fuzzy logic and ANP weighting technique are the benefits of this new approach. managers and evaluators can use this approach to compare the capacity of the regions in terms of three groups of tourism (water, extensive and intensive), and to compare the total tourism land-uses. It is proposed to use this ability to select national strategies of sustainable development in the form of land use planning for assessing large-scale tourism capacity (countries or large privinces).

Although this approach has been presented to assess tourism in Iran, at the same time, considering the innovative approach used in the evaluation method based on the general and specific criteria, use of fuzzy logic in the valuation of criteria, use of the ANP in the prioritization of criteria and land-uses, it is possible to use it in other parts of the world. To use this approach, it is essential to adapt assessment criteria to regional conditions. It should be noted that in each region, the necessary conditions are provided for a limited number of tourism land-uses and consideration of all land-uses in the calculation of the index is for the purpose of make it possible to compare different regions in terms of total tourism capability in large-scale area. 


\section{REFERENCES}

Ahmadi Sani, N., Babaie Kafaky, S., Pukkala, T., \& Mataji, A. (2016). Integrated use of GIS, remote sensing and multi-criteria decision analysis to assess ecological land suitability in multi-functional forestry. Journal of Forestry Research, 27(5), 1127-1135.

Amanpour, S., Mohammadi, A., \& Naser, M. (2012). Ranking of cities of Khozestan province from the view of tourism criterions using TOPSIS model. Journal of Human Geography, 5(1): 201-221.

Asadi, R., \& Daryaei, M. (2011). Prioritization of Forms of Tourism in Iran to Formulate National Strategies. European Journal of Scientific Research, 5(1): 144-152.

Asami, S., Yoda, M., Kino, A., \& Morishige, M., (2009). Tourism Relationship Model and Intermediary for Sustainable Tourism Management: Case Study of the Kiritappu Wetland, Hokkaido, Trust in Hamanaka. BEST EN Think Tank IX. 382-394p.

Berry, J.K. (1991) "GIS in Island Resource Planning: A Case Study in Map Analysis”. In: Maguire, D. et al. (eds) Geographical Information Systems: Volume 2 Applications (pp. 285-95), Harlow, Longman.

Boyd, S.W \& Butler, R.W. (1996), Seeing the forest through the trees: Using GIS to identify potential ecotourism sites in Northern Ontario, in: L.C. Harrison \&W. Husbands (Eds) Practising responsible. Tourism: International case studies in tourism planning, policy \& development, pp. 380-403 (New York: J. Wiley \& Sons).

Boyd, S.W., Butler, R.W., \& Haider, W. (1995). Identifying criteria and establishing parameters for forest-based ecotourism in Northern Ontario, Canada. In: Vander Stoep, Gail A., ed. Proceedings of the 1994 Northeastern Recreation Research Symposium; 1994 April 10-12; Saratoga Springs, NY: Gen. Tech.

Boyd, S., Butler, R.W., \& Haider, W. (1995). Identifying criteria and establishing parameters for forest-based ecotourism in Northern Ontario, Canada. In: Vander Stoep, Gail A., ed. Proceedings of the 1994 Northeastern Recreation Research Symposium; 1994 April 10-12; Saratoga Springs, NY: Gen. Tech.

Cocklin, C., Harte, M., \& Hay, J. (1990). Resource assessment for recreation and tourism: a New Zealand example. Landscape and urban planning, 19(3), 291-303.

Cohen, S., Prayag, G., \& Moital, M. (2014). Consumer behavior in tourism: Concepts, influences and opportunities. Journal Current Issues in Tourism, 17(10): 872-909.

Dezsi, Şt. (2008). Value estimation of tourism potential and material base in Lăpuşului Land in the perspective of regional tourist arrangements, GeoJournal of Tourism and Geosites, year 1, no. 1, vol. 1, pg. 48-62.

Dowling, R.K. (1993). An environmentally based approach to tourism planning. Doctoral Thesis, School of biological an environmental sciences, Murdoch University, Murdoch. 393p.

Eskandari, S., Oladi Ghadikolaei, J., \& Yakhkeshi, A. (2013). Evaluation of Tourism Attract Potential of Sorkhehesar Forest Park Using Systemic Analysis Method. Ecology of Iranian Forest. 1 (1): 60-71. (In Persian).

Ferrario, F.F. (1979). The evaluation of tourist resources:an applied methodology. Journal of Travel Research, 17(3): 18-22.

Ghadiri Masoom, M., Salmani, M., \& Ghassabi, M.J. (2015). Evaluating of Development Potential of Desert Tourism and Its Impact on Socio-economic and Physical Dimension in Rural Settlements (Case Study: Villages of Khoor-o-Biabanak Township). Journal of Geography and Planning, 50 (18): 281304. (In Persian).

Glavan, V. (2000). Tourism and environment protection-previous problems, Romanian Statistics Revue, no. 8-9, Bucharest.

Iatu, C. (2010). A critical analysis on the evaluation of tourism attractiveness in Romania. Case study: the region of Moldavia. The 5th WSEAS International conference on economy and management transformation, Volume I. West University of Timisoara, Timisoara, Romania.

Ielenicz, M., \& Comănescu, Laura (2009), Romania tourist potential, University Publishing House, Bucharest. 464p.

Jokar, P., Masoudi, M., Fallah Shamsi, S-R., \& Afzali, S-F. (2014). Developing a Model for Ecological Capability Evaluation of Ecotourism. International Journal of Scientific Research in Environmental Sciences, 3(1): 1-8.

Karami, O., Maleknia, R., \& Piran, H. (2014). An integrated GIS-based analytic network process to land suitability evaluation for forest park location, case study: Badreh country, Ilam, Iran. Advances in Environmental Biology. 8(2): 342-350.

Lin, L.Z., \& Hsu, Th.O. (2011). Designing a model of FANP in brand image decision- making, Applied Soft Computing, 11: 561-573.

Litton, J.B., (1968). Forest landscape description and inventories basis for land planning and design. US Dep Agric. Forest Service Research Paper, Berkeley. 64p.

Lynch, J.A., \& Gimblett, R.H., (1992). Perceptual values in the cultural landscape: A computer model for assessing and mapping perceived mystery in rural environments. Comput, Environ, and urban systems, $16,453-471$.

Makhdoom, M. (2006). Fundamental of land use planning. 7th edition. TehranUniversity, 289p. (In Persian).

Marzuki, A. (2011). Resident Attitudes towards Impacts from Tourism Development in Langkawi Islands, Malaysia. World Applied Sciences Journal, 12: 25-34.

McClinchey, A.K., \& Carmichael, A.B., (2010). Countryside capital, changing rural landscapes and rural tourism implications in Mennonite Country. Journal of Rural and Community Development, 5, 178-199. 
McHarg , Ian. (1969). Design with Nature. American Museum of Natural History. 197p.

Mitchell, B. (1989). Geography and resource analysis. New York: Longman Scientific and Technical; 2nd edition. 386p. Muntele, I., \& Iațu, C. , (2006). Tourism geography-Concepts, methods, spatial patterns. Sedcom Libris, Iași.

Moss, R. M., \& Nickling, W. G. (1980). Landscape evaluation in environmental assessment and land use planning. Environmental Management, 4(1), 57-72.

Movahedi, S., Amani, H., \& Banikamali, S. (2013). Identification and calculation of tolerance capacity areas prone to ecotourism development in Sabalan Zone. Geography and Environmental Planning Journal, 49(1): 35-38.

Najafifar, A., (2017). Presentation of comprehensive model of land use planning for multiple uses in southern Zagros woodlands (Case study, Ilam Province, Badreh Township, Kabirkooh). A thesis for the degree of $\mathrm{PhD}$ in Silviculture and Forest Ecology. Gorgan University of Agricultural Sciences and Natural Resources. 326p.

Najafifar, A., Moayeri, M.H., Shatai-Joybari, Sh \& Salman-Mahini, A., (2017). The role of hillshade regime on canopy density and evaluation of ecological capability in the Zagros woodlands (Case study: Kabirkooh forest of Badreh city, Ilam province). Iranian Journal of Forest and Poplar Research, Vol. 25 (1): 23-34.

Nakos, G. (1984). The land resource survey of Greece: a tool for land use planning and policy, in "policy Analysis for Forestry Development”. Proc IUFRo-Div. 4. Thesdaloniki: 439-450.

Nasrollahi, Z., Jahanbazi, N., \& Naseri, T. (2014). Classification provinces in the country in terms of tourism gravity. Journal of Tourism Management, 7(3): 17-38. (In Persian).

Schwab, K. (2017). The Travel \& Tourism Competitiveness Report 2017, Paving the way for a more sustainable and inclusive future. World Economic Forum.

O'Riordan, T. (1971). Perspectives on Resource Management. London, Pion. 183 p.

Pirmohammadi, Z., Feghhi, j., Zahedi Amiri, G., \& Sharifi, M. (2010). Environmental capability evaluation appropriate to ecotourism in Zagros forests (Case study: Saman-e-orfie Cham-Haji of Kakareza forest in Lorestan Province). 18(2): 230-241.

Priskin, J. (2001). Assessment of natural resources for nature-baased tourism:in case of the central Coast Region of Western Australia. Journal of Tourism Management, 22, 637-648.

Ringo Linder, G. (2009). Utilizing GIS-Based Site Selection Analysis for Potential Customer Segmentation and Location Suitability Modeling to Determine a Suitable Location to Establish a Dunn Bros Coffee Franchise in the Twin Cities Metro, Minnesota, Volume 11. Papers in Resource Analysis. 11 pp.

Saaty, T.L. (1999). Fundamentals of the Analytic Network Process. Proceedings of ISAHP (1999), Kobe, Japan. August 12-14. 14p.

Smith, R. S. (1982). The use of land classification in resours assessment and rural planning. Natural Environment Research Council Institute of Terrestrial Ecology. Cambridge. 44p.

Smith, S. (1987). Regional analysis of tourism resources. Annals of Tourism Research, 14(2): p 254-273.

Song, M.W; Liang, Y.F; \& Feng D. (2014). Research on the Evaluation Model of Urban Tourism Management Efficiency with Uncertain Linguistic Information. Journal of Control Science and Engineering, (2014): 1-4.

Suvdantsetseg, B., Fukui,H., \& Oe, M. (2011). Evaluation of ecotourism resources through participatory GeoSpatial Approach: A Case of the Biger city, Mongolia. SEAN Journal on Hospitality \& Tourism, Vol 10(2). 162-176.

Suvdantsetseg, B., Fukui,H., \& Tsolmon, R. (2010). Ecotourism development planning in the Biger soum of Gobi-Altai province, Mongolia, paper published at the 4thAnnual International Conference on the Application and Development of Geospatial Technologies in Mongolia, 153-158.

Tsaur, S.H., Lin,Y.C., \& Lin, J.H., (2006). Evaluating ecotourism sustainability from the integrated perspective of resource, community and tourism. Journal of Tourism Management, 27, 640-653.

Yildirim, T.B., AK, T., \& Olmez, Z. (2008). Assessment of the natural-ultural resources in Canakkale for naturebased tourism. Environ Dev Sustain, o:871-881.

Zabardast, E. (2010). The application of Analytic Network Process (ANP) in urban and regional planning. Journal of Fine Arts, Architecture and Urban Planning, Tehran University. 41: 79-90. (In Persian).

*** UNWTO (United Nations World Tourism Organization). (2017). Tourism Highlights 2017 Edition. http://www.e-unwto.org/ doi/book/10.18111/9789284419029. 15p.

Submitted:

o8.04.2018
Revised:

23.09.2019
Accepted and published online 25.09.2019 